\title{
ENVIRONMENTAL MANAGEMENT: AN EVALUATION MODEL FOR BRAZILIAN BACHELOR DEGREE PROGRAMS
}

Luiz Leandro ${ }^{1}$

Elza Neffa ${ }^{2}$

\begin{abstract}
In the last ten years, the Brazilian government has made efforts to build an economic policy that promotes growth and has lead the country to be amongst the world's largest economies. However, such goals highlight the capitalist model of production and consumption while aggravating environmental conflicts faced in recent decades. In the first decade of the 2000s, in an attempt to reconcile economic growth and environmental sustainability, Brazilian universities began implementing training courses in environmental management with the purpose of forming a new class of managers to take the role of decision makers in management processes. With 200 higher education courses in Environmental Management, 10 Bachelor degree programs and 190 technical courses, Brazil stands as an example for the design of such programs. This study presents the process of building a methodology for the evaluation of educational projects of these Environmental Management Bachelor degree programs based on qualitative content analysis using social context, professional profiles and student assessment. Such methodology will be developed as part of a later study which aims to define the profile of Brazilian Bachelor degree programs in Environmental Management and point out ways to build curriculum guidelines.
\end{abstract}

Keywords: Qualitative Analysis; Environment; Higher Education; Management.

\footnotetext{
${ }^{1}$ Universidade Federal Rural do Rio de Janeiro. E-mail: luizleandrorj@globo.com.

2 Universidade do Estado do Rio de Janeiro. Email: elzaneffa@hotmail.com.
}

Revbea, São Paulo, V. 9, Nº 1: 87-101, 2014.

revista brasileira educação ambiental 
Resumo: $O$ governo brasileiro tem realizado esforços para construir uma política econômica que proporcione crescimento de modo a incluir o país entre os maiores produtores e consumidores mundiais. Tais metas realçam o modelo capitalista de produção e de consumo que agrava os conflitos socioambientais enfrentados nas últimas décadas. Como tentativa de conciliação entre crescimento econômico e sustentabilidade as universidades brasileiras iniciaram, na primeira década dos anos 2000, cursos de formação em Gestão Ambiental - GA, com objetivo de formar uma nova classe de gestores para assumirem o papel de tomadores de decisões nos processos gerenciais. Atualmente, o Brasil conta com 200 cursos superiores em GA, sendo 190 tecnológicos e 10 bacharelados. Na perspectiva de traçar o perfil dos cursos de bacharelado em GA no Brasil e apontar caminhos para a construção de Diretrizes Curriculares Nacionais dos cursos em tela, este estudo apresenta 0 processo de construção de uma metodologia para a avaliação dos projetos político-pedagógicos dos cursos de bacharelado em GA oferecidos no Brasil, baseado na análise de conteúdo qualitativa a partir: do contexto social, dos objetivos, do perfil profissional, dos componentes curriculares e dos processos de avaliação adotados nos cursos.

Palavras-chave: Análise Qualitativa; Meio Ambiente; Educação Superior; Gerenciamento.

\section{Introduction}

Society has been experiencing deep structural changes in recent decades. International conferences and studies have warned that human beings, in their social organization, have been relating in a disorganized way to nature (SACHS, 2007; LEFF, 2002; JONAS, 2006; ACSELRAD, 1999) and these changes have progressed with an intensity, depth and speed that has never been seen before.

Critical literature questions this development paradigm, and, as understood by common sense and/or applied to productive organizations and governments, has lead to questioning sustainable development (SD) models adopted by nations and organizations.

Brazil's growth and development goals in the last ten years have aimed at "consolidating a mass consumption market" (MANTEGA, 2003, p.67). Industrial growth has brought together externalities inherent to the industrialization processes that have resulted in an environmental crisis. As a result, discussion about active solutions for such an emerging environmental crisis in the scope of higher education is considered highly relevant.

Since Higher Education Institutions (HEI) are proper spaces for searching for answers to society's evolving issues, potential answers to the crisis can be found within HEls. Environmental Management courses propose the formation of a kind of manager able to deal with the complexity of these environmental issues. 
Since curriculum development is a knowledge-production process in which power relationships support content ordering and social relationship development (LOPES, 2008), a political and pedagogic field is capable of promoting thought by professors and students. This can allow for creation of new ways of knowing society based on the collaboration of reality and socioenvironmental issues for the criticism of the present capitalist model (RIOJAS, 2003).

This article presents a proposal for creating a methodological procedure to help the analysis process for educational projects of Bachelor degree programs in Environmental Management offered in Brazil. This procedure aims at contributing to later study about the assumptions guiding the environmental manager's instruction.

Based on the methodological procedure proposed in this article, this study will be grounded in an exploratory perspective of the qualitative paradigm through document analysis of educational projects of Bachelor degree programs in Environmental Management offered by Brazilian HEls.

\section{The socio-environmental issue in Brazil - brief findings}

Considering its continental dimensions, Brazil is South America's largest country, at $8,514,876.599 \mathrm{~km}^{2}$, the world's fourth largest country considering continuous lands, and fifth largest country considering non-continuous lands (IBGE, 2010). Owner to one of the largest biodiversities in the planet, the country is on the list of the 18 mega-diverse countries concentrating $70 \%$ of the fauna and flora of the world and owning about $10 \%$ of the planet's species and $14 \%$ of its renewable drinking water. Considered a real "farm" for food production, with broad inventory of forest carbon (SCARANO et al., 2010), this data places Brazil on the top of nations with the largest amount of diversity and natural resources ${ }^{3}$ which, in theory, have contributed to its development.

In Brasil, however, a more accurate analysis shows that environmental problems between the enactment of the Federal Decree 23,793/34, an important document related to these issues in the country, and the creation of the Environment Department in the 1970s, point to the fact that the environment is mostly conceived as an element for reproducing the logic of exponential production. It is a country where socio-environmental issues are addressed through structural economic problems and a hybrid economic and

\footnotetext{
${ }^{3}$ We observe that, despite natural resources being an expression criticized by some authors because it addresses nature in a reduced fashion as a plain wealth source, we agree with Sachs (2007) who presents the idea that natural resources are, as the set of all goods present in the natural environment, used, and, most of times, changed by human beings to promote the maintenance and reproduction of its kind. Humankind depends on the use of natural goods (of common use), which are resources for maintaining life. We emphasize that this notion has also a cultural dimension, as it corresponds to the society's estimates about its environment. So, we justify the application of the expression in this text by understanding that it has a broader sense than that commonly used.
} 
ideological system that oscillates between new developmentalism ${ }^{4}$ and neoliberalism 5 .

\section{Higher Education Institutions and environment management programs in Brazil}

HEls can be defined as a "variety of microcosms or resonance boxes enabling thinking, from this very particular scope, about the processes and challenges of society as a whole" (RIOJAS, 2003, p.218). While university space is considered important to the production of knowledge, its evolution is acknowledged as one of the slowest in history. However, considering the advent of an environmental crisis where production is threatened by the scarcity of inputs from natural physical means, society demands that universities graduate professionals meeting its needs.

Observing information available in higher education courses in Brazil (INEP, 2010) in the first decade of the 21st Century, 200 higher education courses in Environmental Management were created, 190 of these being technical courses with a minimum duration of 2 years and 10 being Bachelor degree courses with an average duration of 4 years. The development of these courses indicate that Higher Education is servicing the market and general society while providing for the graduation of an Environmental Manager qualified for solving issues related to the environment at a managerial level. This considers the administration, management and decision-making for the performance of tasks for achieving goals.

Martinéz Alier (2007) says that even if we discuss eco-efficiency and sustainable development issues, there is a confrontation that seems without a solution. In this sense, it is hard to find solutions for the crisis inside a reality fragmented by the logic of rationalist scientific thought. According to Bursztyn (2002), the contemporary university is the space marking the development of our industrial times, a space that witnesses the hegemony of science over

\footnotetext{
${ }^{4}$ In the period after the great Depression in the 1930's and after the II World War, the peripheral countries, raw materials exporters to the North Hemisphere, increased their efforts for the development of their industry plants. That period of industry growth, which in Brazil was expanded from the 1950's to 1970's, was named developmentalist (old developmentalism or national-developmentalism), and was characterized by the industrialization guided by the replacement of imports, based on the domestic market for protecting and growing the industry and major intervention of the state in the production of basic inputs and in the infrastructure area (COLISTETE, 2001; FONSECA, 2004).

5 In Latin America, the so-called neo-liberal ideas have found its most finished expression and systematization in the meeting held in November 1989 at the capital of the United States, which was known as the Washington consensus. The main guidelines of economic policy emerging from this meeting comprised the following areas: 1) tax discipline; 2) prioritization of public expenses; 3 ) tax reform; 4) financial liberalization; 5) exchange regime; 6) commercial liberalization; 7) direct foreign investment; 8) privatization; 9) de-regulation; 10) intellectual property. The basic objectives of the Washington consensus proposals were, on one side, the drastic reduction of the State and the corrosion of the concept of Nation, on the other, the maximum opening to the import of goods and services and the entrance of risk capitals. This was all done the name of a great principle: the absolute sovereign of the self-regulating market in the domestic and international economic relations (BATISTA, 1994 apud GENARI, 2001).
}

Revbea, São Paulo, V. 9, № 1:87-101, 2014. 
nature, and the growth of production, specialization, and the organization of subjects into departments. In universities in general, the reductionist model is considered as the basic means of conceiving this reality and this paradigm is freely adopted by several HEls. This reproduces scientific knowledge that goes against the capitalist industry model in force.

In Brazil, the National Education Guidelines and Framework Law - LDB ${ }^{6}$ (BRAZIL, 1996) says that education, in its institutional form, should be associated with the world of labor and social practice. The same law tries to fit the several undergraduate courses offered in the country through National Curriculum Guidelines - NCG. This shows a curriculum organization more compliant with local and regional realities, overcoming the old mandatory minimum curricula. According to Peleas et al. (2011), the curriculum organization proposed by the NCGs should: 1) be sensitive to the changes occurring in socio-technological contexts; 2) consider the inter-disciplinarity adding the issue of trans-disciplinarity as a goal to be achieved; 3 ) observe the continuity of the graduation process that is not ending at the end of the course, but extends throughout life ; and 4) promote the articulation and the indivisibility between education, research and extension. Through the NGGs, it is possible to expand and give flexibility to curricula through educational projects.

After several phone contacts made between 2010 and 2012, and according to the systematic search made on the $\mathrm{MEC}^{7}$ website where we inserted the keywords National Curriculum Guidelines and Environmental Management, we found out that there are no such guidelines for undergraduate degrees in Environmental Management in Brazil. We emphasize that several random combinations of words (in three attempts per day from July 2009 to January 2013) were made in the search device of the MEC system and none of them gave access to these guidelines, confirming they did not exist. Moreover, we have examined the coordination of the 10 Bachelor degree courses in Environmental Management of the country and none of them demonstrate NCG for Bachelor degree courses in EM.

\section{Educational Projects}

Literature reveals that preparing an undergraduate course is a task demanding more complex action than the plain description of basic and complementary contents around which subjects are organized and distributed over academic terms (GOODSON, 2008; SILVA, 2008; SACRISTAN, 2000; MOREIRA; SILVA, 2006; SILVA, 2008). We believe that the entire pedagogic practice should be inserted in the context of educational projects and it is a basic element for education processes.

\footnotetext{
${ }^{6}$ Leis de Diretrizes e Bases da educação Brasileira (LDB) - guidelines and bases of Brazilian education.

${ }^{7}$ Brazilian Ministry of Education - http://portal.mec.gov.br/
} 
As mentioned, Environmental Management courses in Brazil do not have any National Curriculum Guidelines again. This makes it harder to have the articulation required for the construction of educational projects including the basic dimensions guiding the course. We have pointed out that educational projects should bring together information in its educative intention for revealing the course's identity and to enable the pedagogic actions included in the graduation process to be understood (SACRISTÁN, 2000).

In the sole paragraph of Art. 52, the LDB (1996) provides, that "universities are multi-disciplinary institutions of formation of the staff of higher degree, research, extension and domain and cultivation of the human being [...]" and this knowledge is manifested in the institutionalized intellectual production emerging from systematic study of relevant themes and issues from both scientific, cultural, regional and national points of view.

Given the importance of the problematic grounding of graduation in environmental management and the absence of guidelines establishing the course organization in view of social needs, we consider it essential to proceed to the analysis of educational projects of the Bachelor degree courses of Environmental Management offered in Brazil. While we know most of the country's graduation courses in EM occur in the technical modality, we will analyze only Bachelor degree courses since we consider that the creation of professional identity depends on the formation of researchers and professors to act as instructors in the future as in other professional courses. It is obvious that this instruction occurs in Bachelor degree programs based on the assumption that educational projects for Environmental Management courses are capable of interfering in the rational planning of the several areas comprised by the complex socio-environmental systems.

We agree with Sachs (2007) that world consumption levels, capable of making changes which enable the maintenance and recovery of the biosphere, will only be reached with deep institutional changes. These changes facilitate the adoption of not only single models, but ones that are adaptable to the differences and complexity inherent to environmental issues. According to Mészáros (2011), a revolution in the capitalist system could be the only final solution. However, at this moment, alternatives to the traps of the capitalist system could allow possible revolutionary methods by means of action strategies that allow environmental management to be operational in sustainable and social justice frameworks. In our opinion, Environmental Management courses could be spaces for thinking and disseminating alternatives with a priority of the kind of development that is based on human development and environmental sustainability rather than on progressivism and the exponential growth of capitalist production and consumption. 


\section{The grounds to build the methodological procedure}

Building a methodological procedure able to handle educational projects of Environmental Management courses, we consider eco-development ${ }^{8}$, adapted from Sachs (2007), as an effective development paradigm. Such a concept presents the following dimensions described below:

a) Eco-regional: comprises the acknowledgement and valuation of the materials present in the natural region used for meeting the population's needs regarding food, housing, entertainment, education etc. It is observed that the concept of need should be reworked through educational processes for avoiding the excessive consumption common to developed nations. Noticing this dimension can reduce the pressure for consuming certain classes of products.

b) Human realization: comprises all methods of realization, such as employment, safety and quality of human relations in respect to cultural diversity.

c) Diachronic solidarity: consists of avoiding the wasting of natural resources and increasing the use of renewable resources. In this sense, we agree with Sachs (2007) and Veiga (2010) that nature, while a material base for maintaining humankind, is limited. The adoption of Solidarity Ethics ${ }^{9}$ (JONAS, 2006) can contribute to the double operation of the use of renewable raw materials related to use fitted to the needs of future generations.

d) Eco-technique: implies the development of technologies aimed at energy efficiency through clean sources. This considers the fragilities of eco-systems based upon decision-making regarding projects which generate an impact on communities and the natural environment. This dimension also considers technology as a multidimension variable within environmental planning. According to Sachs (2007), this dimension does not represent technology as means of solving environmental problems. In this case, there is the proposition of a technique with a new perspective from a new technological and educational model.

e) Educational: is performed through formal and informal education and is essential to the eco-development concept since it contributes to the movement of qualitative improvement of the standards of values regarding human positioning regarding nature.

\footnotetext{
${ }^{8}$ This concept was coined by the executive officer of the United Nations Program for the Environment during the first meeting of the Board of Directors, held in Geneva, Switzerland. At first, the concept aimed at proposing a development style for rural areas of developing countries; however, Sachs (2007) proposes to expand it to urban regions.

9 Jonas (2007) and his theories present the possibility of the existence of graded apocalypses resulting from the growing danger of the risk of global technical progress and its improper use. According to him, the range of ethics is reduced to the scope of relationships between people in the present moment that would represent anthropocentric ethics aimed at contemporaneity. The advancement reached by human beings through technology has drastically changed that reality as nature has started to be objectified, treated as something liable to drastic changes due to the wills of the human being. Therefore, for this author, the man-nature relation starts to be based on an issue of responsibility since it is under his own power. This power is capable of interfering in the natural physical environment available for the lives of future generations. That leads us to think about a new set of ethics, responsibility, an escape from anthropocentrism and an ability to comprise the natural world, including the human being itself and its responsibility for future generations. This is what responsibility ethics consist of: a society that, in the present, thinks about strategic alternatives to enable an equal or better future for subsequent generations.
}

$$
\text { Revbea, São Paulo, V. 9, N 1: 87-101, } 2014 .
$$


The eco-development concept is a developmental style where each ecoregion with its specificities seeks solutions to its specific problems, considering not only ecologic, but also socio-cultural data. All this is comparative and redefines the progress, sustainability and development notions, ignoring universal formulas intended to apply to any situation (SACHS, 2007).

Analyzing educational projects of Environmental Management courses requires the observation of the variables involved in consideration of a development economy added to the environment variable. In this model (Figure 1), many aspects must be considered: E: environment $\mathbf{S}$ : society (in general, with all of its peculiarities); $\mathbf{T}$ : technique (technological development); $\mathbf{P}$ : products (goods and services offered to people); R: natural resources (although the expression has a negative connotation in several contexts, its comprehension refers to the material ground required for the maintenance of human needs. Such resources are present in the natural environment).

In the Sachs' (2007) perspective, the merit of observing the relations between those variables lies in the fact that they reveal the relations to be considered in the environment management process, added to the traditional dimensions of planning. We highlight as well that, according to Sachs (2007), variables should be analyzed under the perspective of observing:

i) that the consumption standard depends on the level and profit distribution in addition to the values that each society has to guide it to that standard;

ii) the socio-political system, since in capitalist economies companies traditionally internalize profits and externalize costs. The aspect to examine is the internalization of socio-environmental costs by companies by means of State devices.

iii) the way of using and the choice of energy matrices and other resources resulting from the natural environment. The control of the obsolescence rate and the cleaner production technologies related to the low energy consumption can be important alternatives as they are the indicators of the internalization of the environmental dimension.

iv) several ways land occupation as well as the population's growth levels should be considered. The pressure for the consumption of several agricultural products may result in serious environmental issues, such as the increase in the deforestation rate due to cattle-raising or export monocultures. 
The relations between the variables can happen in several ways and Figure 1 presents some of those inter-relations, according to Sachs (2007):

$\mathbf{R} \Rightarrow \mathbf{E} \& \mathbf{T} \Rightarrow \mathbf{E}:$ the way the resources and production techniques are applied affect the environment

$\mathbf{P} \Rightarrow \mathbf{E}$ : the way consumption impacts the environment

$S \Rightarrow E$ : the impact of human activity on the environment regardless of the consumption of processed products

$\mathbf{E} \Rightarrow \mathbf{R}$ : the 'wear and tear' of the environment when it is seen exclusively as a source of resources and wealth.

$\mathbf{E} \Rightarrow \mathbf{P}:$ how the environment quality affects production

$E \rightarrow S:$ the natural and built environment seen as quality of life component and generator

Figure 1: basic variables involved in consideration of the development economy.

The methodological procedure proposed in this study is an adaptation of the qualitative content analysis of Mayring $(2002)^{10}$. This technique has the main advantage of enabling a strict methodological control without leading the study to quantification unconnected to the analytic social context. The technique divides the material to be construed in units - referred to here as categories ${ }^{11}$ - that should be considered one by one, allowing interpretation in the light of certain prior theoretical reference work. Some kinds of qualitative content analysis are available in the literature. In our case, we have chosen to work with the structural qualitative content analysis which has an objective to filter certain aspects of the material analyzed with the purpose of assessing the content based on certain criteria. This model of analysis enables the

\footnotetext{
${ }^{10}$ This technique was created in the U.S., in the first half of the $20^{\text {th }}$ Century, from studies made in the area of communication sciences, with the purpose of analyzing the mass communication media to check their impact on the American society. At first, such analysis had a qualitative purpose, giving weights and counting the frequency of words in certain texts. However, that analysis gave little consideration to the context of the text elements, the latent sense structures, the remarking individual cases and the information implicit in the text, due to the context in which they were written. That is why an analysis favoring the qualitative aspect of the message in the texts is required (MAYRING, 2002).

${ }^{11}$ These are categories that, in this context, are understood with a different sense from the categories of essential and derivate analysis of Deák (1985). Although they also contribute to the comprehension of a certain reality, they are understood differently, as in this technique they exist to group the textual elements and enable its relation to the context and the theory grounding the analysis. In this case, the document/text is interpreted rather than the social reality itself.
} 
performance of cutting the material's structure and gives room to its filtering, easing the comprehension of senses attributed there.

This model of construction is based on the creation of structuring categories and on the setting of anchors. After reading the theoreticalmethodological referential study, we consider that educational projects should include the dimensions resulting from eco-development: Eco-regional, Human Realization, Diachronic solidarity, Eco-technique and Educational. These dimensions define the group of previous categories. The anchors, which for the purpose of our study are operational variables, should be included in all the structuring categories: (M) environment; (S) society (T) techniques; (P) products; $(R)$ natural resources. The anchor-category codification rule should also be established. We suggest using colors to connecting them to clarify their organization. It is worth observing that, as it is a model guided by the research qualitative paradigm, other categories or anchors can result from the document analysis stage. For a new category to be considered, it should appear significantly and repeatedly in documents, as an expression, concept or idea, and should bring, inside of it, the anchors already included in the study. It is emphasized that the new category should be intrinsically related to the theory included in the theoretical-methodological referential. Creating new anchors, however, requires the repeated inclusion of variables considered as operational and justifiable by the theoretical-methodological referential. It is worth observing that both categories and anchors should consider, upon interpretative analysis, the social context, the objectives, the professional profile, the curriculum components and the evaluation processes adopted in the courses and expressed in the educational projects.

The chart for the process model (Figure 2) and the guide for performing the methodological procedure (Figure 3 ), with categories and anchors to be used in the qualitative content analysis of the educational projects for Bachelor degree programs in Environmental Management offered by the Brazilian HEls, are graphically presented:

One of the main steps for a consistent analysis is a final wording based on the theoretical-methodological referential adopted in the study and presented argumentatively. This should reflect the researcher's interpretation of elements filtered from the written material subsidizing the analysis. 


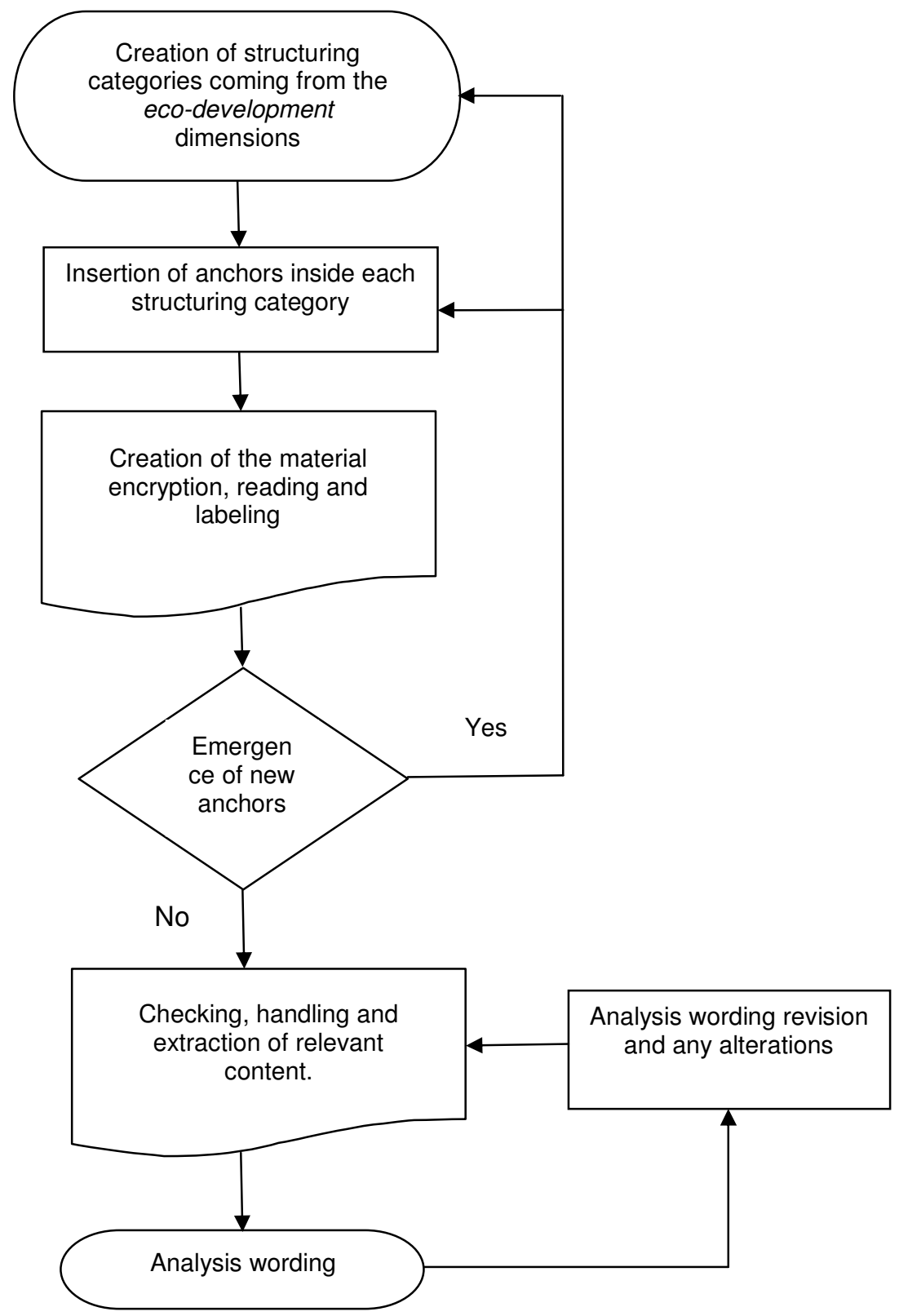

Figure 2: Model of the structuring qualitative content analysis process.

Source: Leandro (2013) Adaptation from Mayring (2002).

Revbea, São Paulo, V. 9, N 1: 87-101, 2014. 


\begin{tabular}{|c|c|}
\hline CATEGORIES & ANCHORS \\
\hline Eco-regional & $\begin{array}{l}\mathbf{R} \mathbf{E} \& \mathbf{T} \mathbf{E} \text { : How the educational project works the use of resources and } \\
\text { production techniques applied that impact on the environment. }\end{array}$ \\
\hline Human & $\begin{array}{l}\mathbf{P} \text { E: How the educational project works the relation the between consumer } \\
\text { and the impacts of consumption on the environment. }\end{array}$ \\
\hline & $\begin{array}{l}\text { S. How the educational project works the relations and the impact of the } \\
\text { human activity on the environment regardless of the consumption of processed } \\
\text { items. }\end{array}$ \\
\hline solidarity & $\begin{array}{l}\text { E R: How the wear and tear of the environment are addressed in the } \\
\text { educational project when nature is perceived exclusively as resource and } \\
\text { source of wealth. }\end{array}$ \\
\hline $\begin{array}{l}\text { Eco- } \\
\text { technique }\end{array}$ & $\begin{array}{l}\text { E P: How the educational project works with the relation existing between } \\
\text { quality and production. }\end{array}$ \\
\hline Educational & $\begin{array}{l}\text { E S: The educational project works with the idea of environment (natural } \\
\text { and built) as quality of life component and generator. }\end{array}$ \\
\hline
\end{tabular}

Figure 3: Guide for the performance of the methodological procedure with categories and anchors. Source: Leandro (2013) - from research data.

\section{Conclusion}

The growth goals disclosed by government publications (VELOSO, 2003; PIETÁ, 2010) do not agree with the socio-environmental agenda oriented to the development that overcomes the logic of the exponential progress towards human development and sustainability.

Criticism of the contemporary capitalist system does not ignore the fact that the system implements strategies for its maintenance and selfreproduction. From this perspective, researchers have been presenting action proposals for the operation of the socio-environmental issues management so as to support the alternative strategies for this development model. This is environmentally predatory and excludes the social point of view.

Brazilian Higher Education Institutions have created Environmental Management courses in Technical and Bachelor degree modalities for responding to this environmental crisis. These recent courses, implemented since the first decade of the 2000s, have no National Curriculum Guidelines 
aiming at pointing to ways of interfering in environmental management. In this sense, they boost the creation of strategies for a new kind of development that, according to Sachs (2007), can be oriented by eco-development principles.

Due to the need of checking assumptions on the formation of environmental managers, we suggest the analysis of the educational projects for Bachelor degree programs in Environmental Management developed in Brazil. We understand that their principles are capable of interfering in the manager's formation to be able to make plans considering the complex socioenvironmental themes.

As a result, this content analysis was adopted as a methodological approach due to systematically distinguishing it from other interpretation and hermeneutic works of text material. According to Mayring (2002), its applications are appropriate for handling material written based on theories. Although studies oriented by the qualitative paradigm, especially those of interpretative base, cannot be mathematically validated, these should be systematized so as to enable the research process to be monitored or replicated if necessary (MAY, 2004; MAYRING, 2002).

In our case, the procedural model for the construction of a methodological formula for the analysis of educational projects of Brazilian Environmental Management courses was set from qualitative content analysis and grounded in the theory of eco-development by Sachs (2007), giving source to the analysis categories and the anchors grounding the study.

Such a perspective is incorporated in the study ${ }^{12}$ that analyzes the conceptual bases on which Bachelor degrees in Environmental Management are offered in Brazil. Considering the Brazilian government's goals of growth and expansion of the country's participation in the international capitalist competitive context, the purpose of contributing to the discussion on the construction of the National Curriculum Guidelines for Bachelor degree programs in Environmental Management can be deemed to be essential.

\section{REFERENCES}

ACSELRAD, H.; LEROY, J.P. Novas premissas da sustentabilidade democrática. Rio de Janeiro: FASE, 1999.

BRASIL. Lei № 9.394, de 20 de dezembro de 1996 Lex: Leis de Diretrizes e Bases da educação Brasileira (LDB), Brasília, 1996

\footnotetext{
12 Doctor's degree thesis by Prof. Dsc. Luiz Leandro named Environmental Management: A study of the formation of Bachelor Degree Programs in Brazil, developed in the scope of the Graduation Course in Environmental Management by the University of the State of Rio de Janeiro/Brazil, guided by Prof. Elza Neffa, Dsc.
} 
BURSZYN, M. (org.) Ciência, Ética e Sustentabilidade: desafios ao novo século. 3 ed. São Paulo: Cortez, 2002.

GENNARI, A.M. Globalização, neoliberalismo e abertura econômica no Brasil nos anos 90. Pesquisa \& Debate, SP, volume 13, n. 1(21), pp. 30-45, 2001.

GOODSON, I.F. As políticas de currículo e de escolarização: abordagens históricas. Petrópolis: Vozes, 2008

IBGE - Instituto Brasileiro de Geografia e Estatística. http://www.ibge.gov.br/home/estatistica/censo2010

INEP - Instituto Nacional de Pesquisas Educacionais Anísio Teixeira / Ministério da Educação - MEC. http://www.inep.gov.br/superior

JONAS, $H$. O princípio responsabilidade: ensaio de uma ética para a civilização tecnológica. Rio de Janeiro: Contraponto: Ed. PUC-Rio, 2006.

LEFF, E. Epistemologia Ambiental. 3 ed. São Paulo: Cortez, 2002.

MANTEGA, G. A nova estratégia de crescimento sustentado. In: VELLOSO, J.P.R. (org.). Governo Lula, novas prioridades e desenvolvimento sustentado. Rio de Janeiro: José Olympio, 2003.

MARTÍNEZ ALIER, J. O ecologismo dos pobres: conflitos ambientais e linguagem de valoração. São Paulo: Contexto, 2007.

MAY, T. Pesquisa social: questões, métodos e processos. 3 Ed. Porto Alegre: Artmed, 2004

MAYRING, P. Einführung in die qualitative Sozialforschung [Introdução à pesquisa social qualitativa]. 5 ed. Weinheim: Beltz, 2002. Disponível em: http://www.unb.br Acesso em: 10 abr 2005.

MÉSZÁROS, I. A crise estrutural do capital. São Paulo: Boitempo, 2011

MOREIRA, A.F.B.; SILVA, T.T. Currículo, cultura e sociedade. 10 Ed. São Paulo: Cortez, 2008.

PIETÁ, E. A nova política econômica, a sustentabilidade socioambiental. São Paulo: Ed. Fundação Perseu Abramo, 2010.

RIOJAS, J. A complexidade ambiental na universidade. In: LEFF, Enrique (org). A complexidade ambiental. Blumenau: Cortez / Edifurb, 2003.

SACHS, I. Rumo à ecossocioeconomia: Teoria e prática do desenvolvimento. São Paulo: Cortez, 2007.

SACRISTÁN, J.G. O currículo: uma reflexão sobre a prática. 3. Ed. Porto Alegre: Artmed, 2000.

SCARANO, F.R.; GASCON, C.; MITTERMEIER, R.A. O que é biodiversidade? Scientific American. Brasil. Edição especial. n. 39, julho 2010.

SILVA, M.R. Currículo e competências: a formação admiministrada. São Paulo: Cortez, 2008. 
SILVA, T.T. Documentos de identidade: uma introdução às teorias do currículo. Belo Horizonte: Autêntica, 2006.

SIQUEIRA , H.S.G. Formação interdisciplinar: exigência sociopolítica para um mundo em rede. In: SIMPÓSIO ESTADUAL DE ECONOMIA DOMÉSTICA, 7., 2003, Francisco Beltrão, PR. Anais eletrônicos. Francisco Beltrão, PR: UNIOESTE, $2003 . \quad$ Disponível em: http://www.angelfire.com/sk/holgonsi/mundorede.html. Acesso em 19 de março 2013.

VEIGA, J.E. Desenvolvimento sustentável: o desfio do século XXI. Rio de Janeiro: Garamond, 2010.

VELLOSO, J.P.R. (org.). Governo Lula, novas prioridades e desenvolvimento sustentado. Rio de Janeiro: José Olympio, 2003. 